\title{
Detection of fowl adenovirus $D$ strains in wild birds in Poland by Loop-Mediated Isothermal Amplification (LAMP)
}

\author{
Jowita Samanta Niczyporuk*, Wojciech Kozdruń, Hanna Czekaj, Natalia Styś-Fijoł and Karolina Piekarska
}

\begin{abstract}
Background: The present study on the role of strains of adenovirus in wildlife reservoirs, and their prevalence is under exploration. In several previous studies, the presence of adenovirus strains in wild birds has been investigated. Worldwide distribution and outbreaks of adenovirus infections have been reported by many authors. The present study investigated the prevalence of FAdVs in 317 samples of different bird species from the northwestern region of Poland. An applied specific, sensitive, and efficient, without cross-reactivity loop-mediated isothermal amplification (LAMP) method to gauge the prevalence of fowl adenovirus strains in wild birds was developed and used.

Results: The method was based on the sequence of the loop L1 HVR1-4 region of the hexon gene of the FAdV genome reference strains FAdV-2 KT862805 (ANJ02325), FAdV-3 KT862807 (ANJ02399) and FAdV-11 KC750784 (AGK29904). The results obtained by LAMP were confirmed by real-time PCR. Among 317 samples obtained from wild birds, eight FAdV isolates (2.52\%) were identified and produced a cytopathic effect (CPE) in chicken embryo kidney cells (CEK). Three FAdV types belonging to species Fowl adenovirus D were detected, which were isolated from three adenovirus types 2/3/11, and have been confirmed in three mute swans (Cygnus olor), three wild ducks (Anas platyrhynchos), one owl (Strigiformes), and one common wood pigeon (Columba palumbus).
\end{abstract}

Conclusions: This study provides the first accurate quantitative data for the replication of fowl adenovirus strains in wild birds in Poland, indicating adenovirus interspecies transmission, and demonstrating the circulation of FAdVs in wild birds.

Keywords: Interspecies transmission, LAMP, Virus strains, Wild birds

\section{Background}

Adenoviruses belong to the Adenoviridae family, and are non-enveloped double-stranded DNA viruses [1]. The conserved domains are responsible for specific structure of molecule, and for trimer formation [2,3]. The highly variable domains are located mainly outside of the virion, and are responsible for the antigenic properties of the virus strains $[1,4]$. The International Committee on the Taxonomy of Viruses [2] separated the Adenoviridae family into five genera: Mastadenovirus, Aviadenovirus, Siadenovirus, Atadenovirus, and Ichtadenovirus. Fowl adenoviruses (FAdV) are separated into five species designated as Fowl adenovirus $A$ to Fowl adenovirus $E$ with 12 types Fowl adenovirus $1-8 a-8 b$ and 11 . FAdVs are a

\footnotetext{
* Correspondence: jowita.niczyporuk@piwet.pulawy.pl

Department of Poultry Diseases, National Veterinary Research Institute, Partyzantow 57, 24-100 Pulawy, Poland
}

very divergent pathogens with generally a low level of virulence [4], however, under certain conditions, they can cause a variety disorders in domestic and wild birds $[2,4,5]$. Adenoviral infections may manifest themselves as asymptomatic or as complication factors in the course of different diseases $[1,4]$. They can be infectious for fish, reptiles, amphibians, birds, and mammals, and have been isolated from over 40 vertebrate species $[1,2,6,7]$. Wild birds with fowl adenovirus infections have been documented by Kumar [8], being presented in falcons [9-11], common buzzards [12], black kite [8], tawny frogmouths [13], psittacines [7, 14, 15] and pigeons [16]. It is possible that under some conditions, fowl adenoviruses may be more virulent in non-host-adapted species than in their typical ones [4]. Some virulent strains, can pass the species barrier, and infect new organisms $[4,17]$. They can transmit horizontally [4], and vertically [18].

(c) The Author(s). 2020 Open Access This article is distributed under the terms of the Creative Commons Attribution 4.0 International License (http://creativecommons.org/licenses/by/4.0/), which permits unrestricted use, distribution, and 
The detection of fowl adenoviruses is very important from an epidemiological point of view. Gunes [19] developed real-time PCR for the detection and quantitation of FAdV(A-E) species, however, in their study, the designed primers were based on the conserved nucleotide sequence of the $52 \mathrm{~K}$ gene with an efficiency of $98 \%$, and regression square values of $R^{2}=0.999$. Different realtime PCR and a subsequent high-resolution melting curve analysis (HRM) of the $191 \mathrm{bp}$ region of the hexon gene, and restriction enzyme analysis have been performed by Steer et al. [20] for differentiating all FAdVs species, and the melting curve profiles were found to be related mainly to GC composition and distribution through the amplicons.

The objective of the present study was to estimate the number of wild birds infected by FAdVs in a forest environment, estimated the geographical distribution of this agent in the region, and perform and applied loopmediated isothermal amplification for the detection of fowl adenovirus strains and designation the adenovirus species/types.

\section{Results}

\section{Sample collection}

The specification of wild bird species which have been used for the study were presented in Table 1.

\section{Virus isolation}

The field and reference strains were propagated in CEK cultures. Three passages were conducted, each of them for $96 \mathrm{~h}$. In the third passage, the first CPE was recognised in about $18-24 \mathrm{~h}$ post infection. The cells were bigger, rounder, and filled with granules. Over the following days, the quantity of damaged cells increased and covered the surface of the bottles. Changes in the $\mathrm{pH}$ of the medium were observed, and these also had an influence on the damaged cells. CPE with different intensity was observed and presented in Fig. 1a-j field strains A)$1 / \mathrm{Msw} 1 / 16(\mathrm{Msw}=$ mute swan $), \mathrm{B})-2 / \mathrm{Msw} 2 / 16(\mathrm{Msw}=$ mute swan), C)-3Msw3/16 (Msw = mute swan), D)$4 \mathrm{Wd} 1 / 16$ (Wd = wild duck), E)5-Wd2/16 (Wd = wild duck), F)6-Wd3/16 (Wd = wild duck), G)7-owl1/16 (owl = owl), H)8-wpi1/16 (wpi = wood pigeon). Positive and negative controls are also presented in Fig. 1a-j.

\section{Virus identification and detection}

Tissue Culture Infectious Doses of field strains were determined in the 3rd passage as $3 \log _{10} \mathrm{TCID}_{50} / \mathrm{ml}$ for FAdV2/3/11/D respectively. In the next step of the study, total DNA was isolated and real-time PCR was applied. The optimal concentration of master-mix was set as $12.5 \mu \mathrm{l}(\mathrm{u} /$ $\mu \mathrm{l})$. For total DNA, the optimal volume was chosen as $2.0 \mu \mathrm{l}$ of DNA for FAdV with a concentration of $10 \mathrm{ng} / \mu \mathrm{l}$, and a pair of primers with a concentration of $10 \mathrm{mM}$, and volumes of $1.5 \mu \mathrm{l}$ each. Sequences of the designed primers and their location in region of the hexon gene for LAMP method are presented in Table 2, and the sequences of the designed primers and their location in region of the hexon gene are presented in Table 3. No real-time PCR curve was observed in the case of the negative control, nor for DNA obtained from other viruses (Fig. 2). The results of each reaction were determined by the calculation of the $\mathrm{Ct}$ values. In the next step, the sensitivity of real-time PCR was determined at the highest dilution of DNA in which a positive result was present with $10^{2.0} \mathrm{ng} / \mu \mathrm{l}$ DNA for FAdV-2/D, FAdV-3/D and FAdV-11/D respectively (Fig. 3). The primers were the most effective in $1.0 \mu \mathrm{l}$ with a concentration of $10 \mathrm{ng} / \mu \mathrm{l}$ at $55^{\circ} \mathrm{C}$, amplicons of standard and field isolates correspond to the predicted curves compared to LAMP sensitivity which was determined according to Niczyporuk [21] as $10^{2.0} \mathrm{ng} / \mu \mathrm{l}$ of DNA.

\section{LAMP visualization}

LAMP showed a fluorescence in the positive control, and in $8(2.52 \%)$ out of 317 DNA samples extracted from field specimens, marked as: A)-1/Msw1/16-2/D, B)-2/Msw2/16-2/D, C)-3Msw3/16-2/D, D)-4Wd1/162/D, E)5-Wd2/16-11/D, F)6-Wd3/16-11/D, G)7-owl1/ 16-11/D, H)8-wpi1/16-11/D, and have been presented in (Fig. 4a). Also specific bands were observed in electrophoresis only with the positive control and positive samples (Fig. 4b).

\section{Real-time PCR quantification}

In the next step of the study, real-time PCR was used for the analysis of field samples as a confirmation of the results obtained by LAMP. The real-time PCR showed the presence of fluorescence curves indicating the presence of adenovirus DNA in the positive control, and eight field samples designated as A-H, and positive control as PC (Fig. 5). A melting curve analysis creates a similar melting temperature $\mathrm{Tm}=$ $73.74{ }^{\circ} \mathrm{C}$ (Fig. 5) with $R^{2}=0.987$, and efficiency $=98 \%$ for all amplified products which reacted. This peak was not observed in either the negative control nor negative samples. In eight among 317 DNA samples, the fluorescence curves were observed. The sequencing analysis of obtained amplicons indicated that detected virus strains were designated as types/species, FAdV-2/3/11/D (Fig. 6).

The samples detected by LAMP and quantified by real-time PCR were derived from different wild bird species which were as follows: three mute swans (Cygnus olor), three wild ducks (Anas platyrhynchos), one owl (Strigiformes), and one common wood pigeon (Columba palumbus).

\section{Discussion}

Fowl adenoviruses are a very diverse group of agents, causing diseases in domestic and wild birds. Fowl 
Table 1 Specification of wild bird species used for the study

\begin{tabular}{|c|c|c|c|}
\hline Species & Number of birds & Places & Region \\
\hline Mallard (Anas platyrhynchos) & $9 / 3^{a}$ & Kuźnia & Pomeranian voivodeship \\
\hline Crow (Corvus corone cornix) & 40 & Kuźnia & Pomeranian voivodeship \\
\hline Garganey (Anas querquedula) & 13 & Gdynia & Pomeranian voivodeship \\
\hline Common Cuckoo (Cuculus canorus) & 4 & Gdańsk & Pomeranian voivodeship \\
\hline Pied Flycatcher (Ficedula hypoleuca) & 3 & Reda & Pomeranian voivodeship \\
\hline Common Kestrel (Falco tinnunculus) & 3 & Stara Kiszewa & Pomeranian voivodeship \\
\hline Jackdaw (Corvus monedula) & 13 & Gdańsk & Pomeranian voivodeship \\
\hline Song Thrush (Turdus philomelos) & 12 & Kartuzy & Pomeranian voivodeship \\
\hline Magpie (Pica pica) & 10 & Gdynia & Pomeranian voivodeship \\
\hline Whitethroat (Sylvia communis) & 1 & Starkowo & Pomeranian voivodeship \\
\hline Willow Warbler (Phylloscopus trochilus) & 4 & Kiezmark & Pomeranian voivodeship \\
\hline Thrush Nightingale (Luscinia luscinia) & 7 & Władysławowo & Pomeranian voivodeship \\
\hline Common Guillemot (Uria aalge) & 6 & Trąbki Wielkie & Pomeranian voivodeship \\
\hline Velvet Scoter (Melanitta fusca) & 4 & Nowy Dwór & Pomeranian voivodeship \\
\hline Black-headed Gull (Chroicocephalus ridibundus) & 2 & Osówek & Pomeranian voivodeship \\
\hline Great Crested Grebe (Podiceps cristatus) & 1 & Żukowo & Pomeranian voivodeship \\
\hline Robin (Erithacus rubecula) & 9 & Pruszcz Gdański & Pomeranian voivodeship \\
\hline Long-tailed Tit Aegithalos caudatus & 2 & Piła & Pomeranian voivodeship \\
\hline Montagu's Harrier (Circus pygargus) & 1 & Cedry Wielkie & Pomeranian voivodeship \\
\hline Common wood pigeon (Columba livia) & $1^{a}$ & Dobrogoszek & Pomeranian voivodeship \\
\hline Goldcrest (Regulus regulus) & 5 & Kościerzyna & Pomeranian voivodeship \\
\hline Common Treecreeper (Certhia familiaris) & 2 & Reda & Pomeranian voivodeship \\
\hline Blackcap (Sylvia atricapilla) & 2 & Borzestowska huta & Pomeranian voivodeship \\
\hline Mute swans (Cygnus olor) & $4 / 3^{a}$ & Luzino & Pomeranian voivodeship \\
\hline Common buzzard (Buteo buteo) & 2 & Sierakowice & Pomeranian voivodeship \\
\hline Raven (Corvus corax) & 5 & Lębork & Pomeranian voivodeship \\
\hline Goshawk (Accipiter gentilis) & 17 & Nowy Dwór & Pomeranian voivodeship \\
\hline Common pheasant (Phasianus colchicus) & 14 & Tczew & Pomeranian voivodeship \\
\hline Common Chiffchaff (Phylloscopus collybita) & 1 & Rusociń & Pomorskie voivodeship \\
\hline Common Swift (Apus apus) & 9 & Miechucino & Pomorskie voivodeship \\
\hline Capercaillie (Tetrao urogallus) & 1 & Reda & Pomorskie voivodeship \\
\hline Eurasian Coot (Fulica atra) & 11 & Sopot & Pomeranian voivodeship \\
\hline White Stork (Ciconia ciconia) & 27 & Goręczyno & Pomeranian voivodeship \\
\hline Spotted Flycatcher (Muscicapa striata) & 3 & Dobrzewino & Pomeranian voivodeship \\
\hline Paridae (Passeriformes) & 11 & Kowalewo & Pomeranian voivodeship \\
\hline Long-tailed Duck (Clangula hyemalis) & 8 & Chojnice & Pomeranian voivodeship \\
\hline Great Cormorant (Phalacrocorax carbo) & 4 & Strzebielino & Pomeranian voivodeship \\
\hline Horned Grebe (Podiceps auritus) & 2 & Lewinko & Pomorskie voivodeship \\
\hline Common Merganser (Mergus merganser) & 1 & Chojnice & Pomorskie voivodeship \\
\hline Grey Partridge (Perdix perdix) & 2 & Gdańsk & Pomorskie voivodeship \\
\hline Eurasian Bittern (Botaurus stellaris) & 5 & Bojano & Pomorskie voivodeship \\
\hline Common Blackbird (Turdus merula) & 1 & Gdynia & Pomorskie voivodeship \\
\hline Great Tit (Parus major) & 1 & Gdańsk & Pomeranian voivodeship \\
\hline Owl (Strigiformes) & $1 / 1^{\mathrm{a}}$ & Goręczyno & Pomeranian voivodeship \\
\hline
\end{tabular}


Table 1 Specification of wild bird species used for the study (Continued)

\begin{tabular}{llll}
\hline Species & Number of birds & Places & Region \\
\hline Eurasian Siskin (Carduelis spinus) & 1 & Czapielska & Pomeranian voivodeship \\
Eurasian Reed Warble (Acrocephalus scirpaceus) & 2 & Jagatowo & Pomeranian voivodeship \\
Lesser Whitethroat (Sylvia curruca) & 1 & Przodkowo & Pomeranian voivodeship \\
Garden Warbler Sylvia borin & 13 & Tuszkowy & Pomorskie voivodeship \\
Common Cuckoo (Cuculus canorus) & 17 & Sobieszewo & Pomeranian voivodeship \\
& & & Total \\
\hline
\end{tabular}

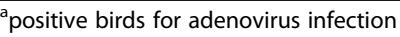

adenoviruses are common in healthy birds as a ubiquitous pathogen, and can cause different diseases with mortalities ranging from $10 \%$ up to $90 \%$, depending on the strain virulence observed in wild birds all over the world [4, 7]. The first adenovirus isolation from wild birds was described by McFerran [6]. Worldwide distribution and outbreaks of adenovirus infection in 40 wild birds species have been reported by many authors [12-14]. In the species Falcon adenovirus A belonging to the genus Aviadenovirus infection has been documented in merlins (Falco columbarius) [10], American kestrels (Falco sparverius), and Mauritius kestrels (Falco punctatus) [9], common buzzards (Buteo buteo) [12] red-bellied parrots (Poicephalus rufiventris) [7] and in tawny frogmouths (Podagrus strigoides) [13]. Strains pathogenic for poultry types FAdV-1/A and 4/ $C$, are not always infectious for wild birds $[2,5]$. Some adenoviruses were not virulent in their natural hosts, and may be more virulent when they cross the species barrier $[2,22]$ and, as in this study, where the FAdV-2/3/11/D has been isolated from wild birds. It is possible that Kites (Milvus migrans) can be infected after the consumption of sick chickens [8]. Different molecular diagnostic techniques have been used for adenovirus detection in wild bird samples [3, 8, 19, 21-27]. In some cases, detection was based on virus isolation, and serological investigation such as: agar gel immunodiffusion (AGID), enzyme-linked immunosorbent assays (ELISA), sero neutralisation (SN), and immunofluorescence essay (IFT) [28]. Because of the variability of the hexon gene in the nucleotide sequence, there is the possibility to differentiate several adenovirus types by real-time PCR and its modifications based on special primers and probes which have been designated for different adenovirus type/species $[4,17,22]$. Most of the studies were also conducted on serological methods, and avian adenovirus group-specific antibodies in serum samples of wild birds have been determined by AGID, SN, IFT, and ELISA [28]. Although in serologic studies it was impossible to discover which species can cause disease or if these birds were infected with avian or different adenovirus species [28]. The serologic survey reveals evidence of the natural exposure of free living common buzzards (Buteo buteo) in Germany, and the presence of adenovirus infection in Eurasian buzzards (Buteo buteo) [12].

Adenoviruses have been identified by electron microscopy in tissue samples from a Northern aplomado falcon (Falco femoralis septentrionalis) affected with inclusion body hepatitis and enteritis. Infection was confirmed in the brain sample of a goshawk (Accipiter gentilis) with neurological signs [29]. The presence of adenovirus strains were detected in a free-living tawny frogmouth (Podargus strigoides) in Australia with hemorrhagic enteritis symptoms described by Reece and Pass [13]. In the USA, Schelling [29] identified adenovirus infection in merlin ( $F$. columbarius) with hepatitis disorders, and infection has also been detected by Forbes in 1997 in the UK in Mauritius kestrels (F. punctatus) with haemorrhagic enteritis, hepatitis, and sudden death.

A new pathogenic adenovirus species isolated from falcons has been recognised [11], which was very similar to fowl adenovirus types FAdV-1/A and 4/C. In our study, types/species 2/3/11/D have been detected. Primary lesions in affected falcons indicates inclusion body hepatitis, splenomegaly, and enteritis [11]. Adenoviral Gizzard Erosion (AGE) in broiler chickens, described as gizzard erosion and ulceration can lead to increasing mortality in a flocks however mostly lead to growth retardation caused mainly by type FAdV-1/A which was recognised over the last decade in Poland, and a specific method for detection, has been developed by Niczyporuk et al. [23] and Niczyporuk [21].

The results obtained by LAMP were fully confirmed by real-time PCR. Methods in birds was previously described by Xie [30] and in wild birds by Gunes [19]. The sensitivity allowed for a minimum detection limit of 9.4 viral genome copies. This was higher than the method obtained in this study with a sensitivity of 8 viral genome DNA copies $/ 1 \mu \mathrm{l}$. The sensitivity was comparable with nested-PCR, and was 100 times more sensitive than conventional PCR. Other researchers also described PCRs for adenovirus detection in wild birds [7, 8, 15], and Heim [31] developed, optimised and performed real-time PCR for the detection of adenovirus strains in 


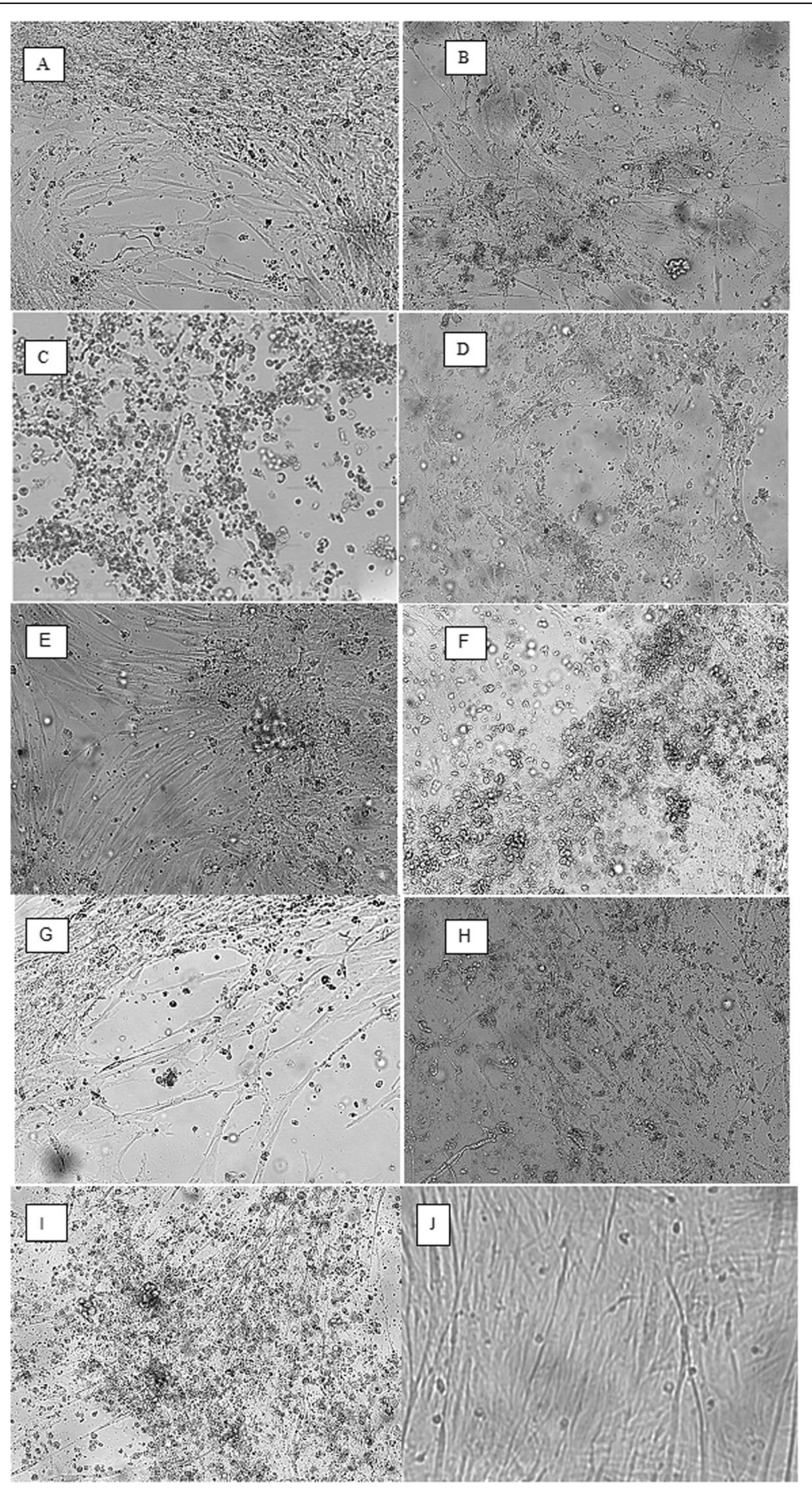

Fig. 1 a-h Characterisation of growth of FAdV strains in CEK cells. Observation on formation of CPE Characteristic cytopathic effect were observed at $96 \mathrm{~h}$ after inoculation with the $3 \mathrm{rd}$ passage of FAdVs strains. The TCID 50 of the strains were between $10^{4.0} / \mathrm{ml}$ to $10^{5.5} / \mathrm{ml}$ on CEK cultures $\mathbf{a}-1 /$ Msw1/16-2/D, b -2/Msw2/16-2/D, c -3Msw3/16-2/D, d -4Wd1/16-2/D, e 5-Wd2/16-11/D, f 6-Wd3/16-11/D, g 7-owl1/16-11/D, h 8-wpi1/16-11/ D. i-j Positive control, CEK cultures infected with adenovirus strain FAdV-2/D in doses of $10^{3.0}{ }^{3} \mathrm{CID}_{50}$, negative control, non infected CEK cultures. The pictures were taken at $72 \mathrm{~h}$ after inoculation

psittacine birds and humans, with concentrations ranging from 10 down to 8 copies per reaction. The sensitivity of real-time PCR using the SYBR Green chemistry
PCR product is 6.6 and could not be detected in gel, however, the amplification plot and melting curves demonstrated specific fluorescence for adenoviruses. 
Table 2 The positions of designed primer sequences within the hexon gene in the genome of FAdV-2/D KT862805 (ANJ02325), FAdV-3/D KT862807 (ANJ02399), and FAdV-11/D KC750784 (AGK29904) used in LAMP loop-mediated isothermal amplification

\begin{tabular}{lllll}
\hline Gene & Name & Sequence & Genome Location & No. of bp. \\
\hline hexon & F3 JSN & 5'ACAACTACCTGTGGACCGT 3' & $20,863-20,879$ & 19 \\
hexon & B3 JSN & 5' CGTTCGGGTTGGTCACC 3' & $21,041-21,059$ & 18 \\
hexon & LF JSN & 5' GGATTCTGACCCAGGTCCGT 3' & $20,917-20,936$ & 20 \\
hexon & LB JSN & 5' CGAGAACACKTACGTSTACAT 3' & $20,995-21,014$ & 21 \\
hexon & FIP(F1C+F2)JSN & 5'TGCTGTGCGAGTGTTGGTGTATTTTCATGTACATGGGCGAACTG 3' & $20,896-20,916 / 20,941-20,962$ & 46 \\
hexon & BIP(B1C+ B2)JSN & 5'ACTTCGAGTTGGACCCCATGGATTTATGTCGAACACGCCGTAGA 3' & $20,971-20,993 / 21,017-21,035$ & 45 \\
\hline
\end{tabular}

The assay specific for targeting the fiber gene was not as sensitive as the one designated for the hexon gene. The fiber gene mRNA was presented in lower copy numbers than the hexon gene in mRNA [32]. Real-time PCR and LAMP for FAdV detection were 1000 times more sensitive than conventional PCR, duplex-PCR $10 \mathrm{TCID}_{50}$ or triplex-PCR $10^{2.0} \mathrm{TCID}_{50}$ developed in a previous study by Niczyporuk et al. [23] and Niczyporuk [21]. Fowl adenovirus strains which had crossed the species barrier were present in approx. $2.52 \%$ of specimens of collected wild birds between 2015 and 2018 .

\section{Conclusion}

In conclusion, for the first time Xie et al. [30] developed LAMP method for the detection and identification of fowl adenovirus strains. To our knowledge this is the first study in which LAMP assay was applied for the detection of fowl adenoviruses in wild bird samples with the primers designed based on the basic sequences of the hexon gene which confirmed the specificity. During the study, in $8(2.52 \%)$ out of 317 examined wild birds, the presence of fowl adenovirus strains was confirmed. The study on adenovirus strains in wild birds in Poland will be continued and the possible infection, and crossspecies transmission between domestic and wild birds will be investigated. In addition the LAMP assay may be a useful alternative for the differential diagnosis of FAdVs. It is noteworthy that, although the quality of the analysed samples is characterised as low detectable viral load, the technique presented a good response in the detection. Comparing with real-time PCR which is cost consuming and the special equipment is needed in front of LAMP advantages.

\section{Methods \\ Standard FAdV strains}

FAdV-A-E standard strains were obtained as lyophylisates from (Charles River, US). The strains were propagated on CEK cultures, and the Tissue Culture Infection Dose $\left(\mathrm{TCID}_{50}\right)$ virus titers were determined according to the Reed-Muench model [33].

\section{Other avian viruses}

Chicken anaemia virus (CAV) $10^{4.5} \mathrm{TCID}_{50} / \mathrm{ml}$ vaccine strain isolated from commercial vaccine, Siadenovirus, Hemorrhagic Enteritis Virus (HEV) reference strain obtained from ATCC with a virus titre of $10^{4.5} \mathrm{TCID}_{50} / \mathrm{ml}$ and Atadenovirus, EDS (DAdV-1) with a virus titre of $10^{4.5} \mathrm{TCID}_{50} / \mathrm{ml}$ reference strain from ATTC collection have been used.

\section{Sample collection}

All birds selected for sampling were submitted for diagnosis were dead. Three hundred seventeen samples were collected from September 2015 to October 2018 from internal organs such as the spleen, liver, gizzards, intestine, and other pathologically changed tissues obtained from wild birds. The samples were derived and collected from different regions of Poland (Table 1). The samples were subjected to the LAMP method using the hexon gene Loop L1 region as a target. Every sample was examined separately by LAMP, and confirmed by real-time

Table 3 The positions of designed primers and probe within hexon gene in the genome of FAdV-2/D KT862805(ANJ02325), FAdV3/D KT862807 (ANJ02399) and FAdV-11/D KC750784 (AGK29904) used in Real - time PCR

\begin{tabular}{lllll}
\hline Gene & Name & Sequence & Genome Location & Amplicon size \\
\hline hexon & FAdV JSN-F & 5'AATGTCACNACCGARAAGGC 3' & $20,666-20,685$ & 93 \\
hexon & FAdV JSN-R & 5'CBGCBTRCATGTACTGGTA 3' & $20,759-20,739$ & 93 \\
hexon & JSN-FAdV probe & 5' $^{\prime}$ AATCCCTACTCGAACACCCC 3' & $20,739-20,760$ & - \\
\hline
\end{tabular}

NRB - degenerated bases 


\section{a}

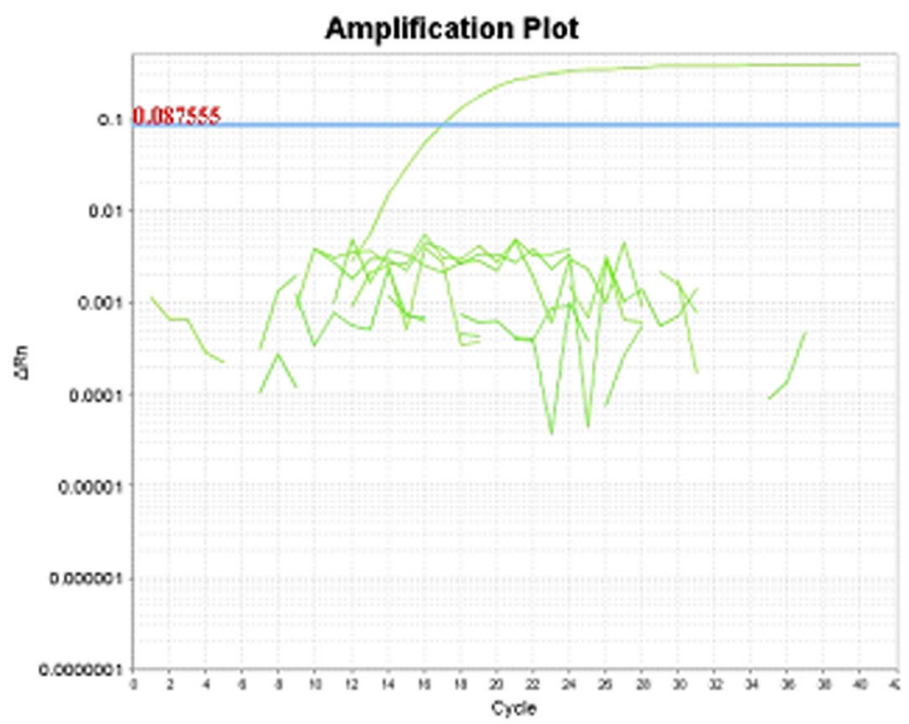

$\mathrm{b}$

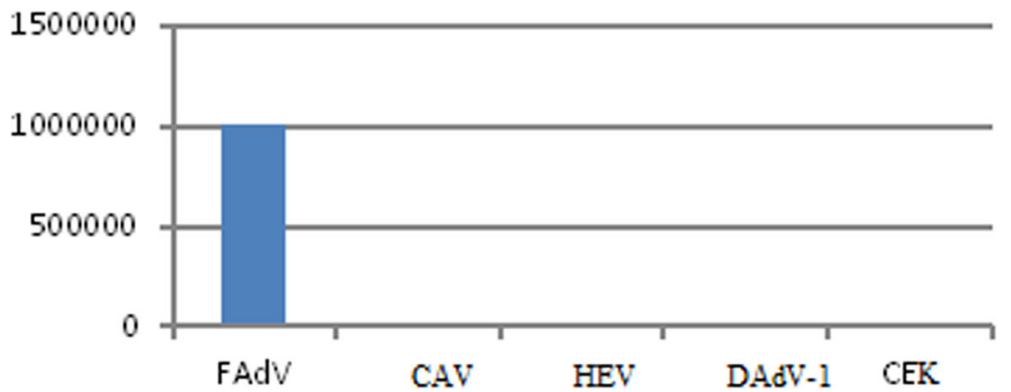

Fig. 2 a Specificity of real-time PCR amplification melting temperature analysis of PCR products recorded in ABI 7500 Real-time PCR system (Applied Biosystems, Foster City, CA). Descriptions: NC - DNA extracted from non infected SPF chicken kidneys (CEKs). b Specificity NC - DNA extracted from non infected SPF chicken kidneys (CEKs). No real-time PCR curve was observed in the case of the negative control, nor for DNA obtained from other viruses: CAV, HEV, DAdV. Rel-time PCR curve was observed in the case of FAdV infection

PCR. The samples were stored and archived at $-20^{\circ} \mathrm{C}$ for the next stage of the study.

\section{CEK cultures}

CEK cultures were prepared from 18 to 19 day old SPF chicken embryos (Lohman, Tierzucht, Cuxhaven, Germany) according to the standard procedure. The growth medium consisted of Eagle's medium (MEM) with the addition of $10 \%$ of foetal bovine serum, and $0.1 \%$ of antibiotic mixture (Antibiotic-Antimycotic, Gibco, Scotland). The maintenance medium consisted of MEM with $0.1 \%$ of antibiotic mixture. A monolayer of CEK cultures was obtained after $18-24 \mathrm{~h}$ incubation at $37.5^{\circ} \mathrm{C}$ in an atmosphere of $5 \% \mathrm{CO}_{2}$.

\section{Isolation of adenovirus strains}

After homogenisation, the tissue samples were submitted to three freeze-thaw cycles, filter sterilised through a
Millipore filter with pores $450 \mathrm{~nm}$ in diameter, and $1 \mathrm{ml}$ was used to inoculate nearly confluent CEK cells. The cell cultures were incubated for 5 days at $37.5^{\circ} \mathrm{C}$ in a $5 \%$ $\mathrm{CO}_{2}$ atmosphere until the onset of the cytopathic effect. The samples which were found positive by LAMP and confirmed by real-time PCR were tested for virus isolation. When CPE was observed after three blind passages, the samples were considered to be positive.

\section{DNA extraction}

Total DNA was extracted directly from prepared inoculates from the internal organs obtained from wild birds. The isolation was performed according to the commercial procedure using a DNA Mini Kit (Qiagen, Germany) from $200 \mu \mathrm{l}$ of cell suspension. The extracted DNA templates were frozen and stored at $-20^{\circ} \mathrm{C}$ until analysis. 


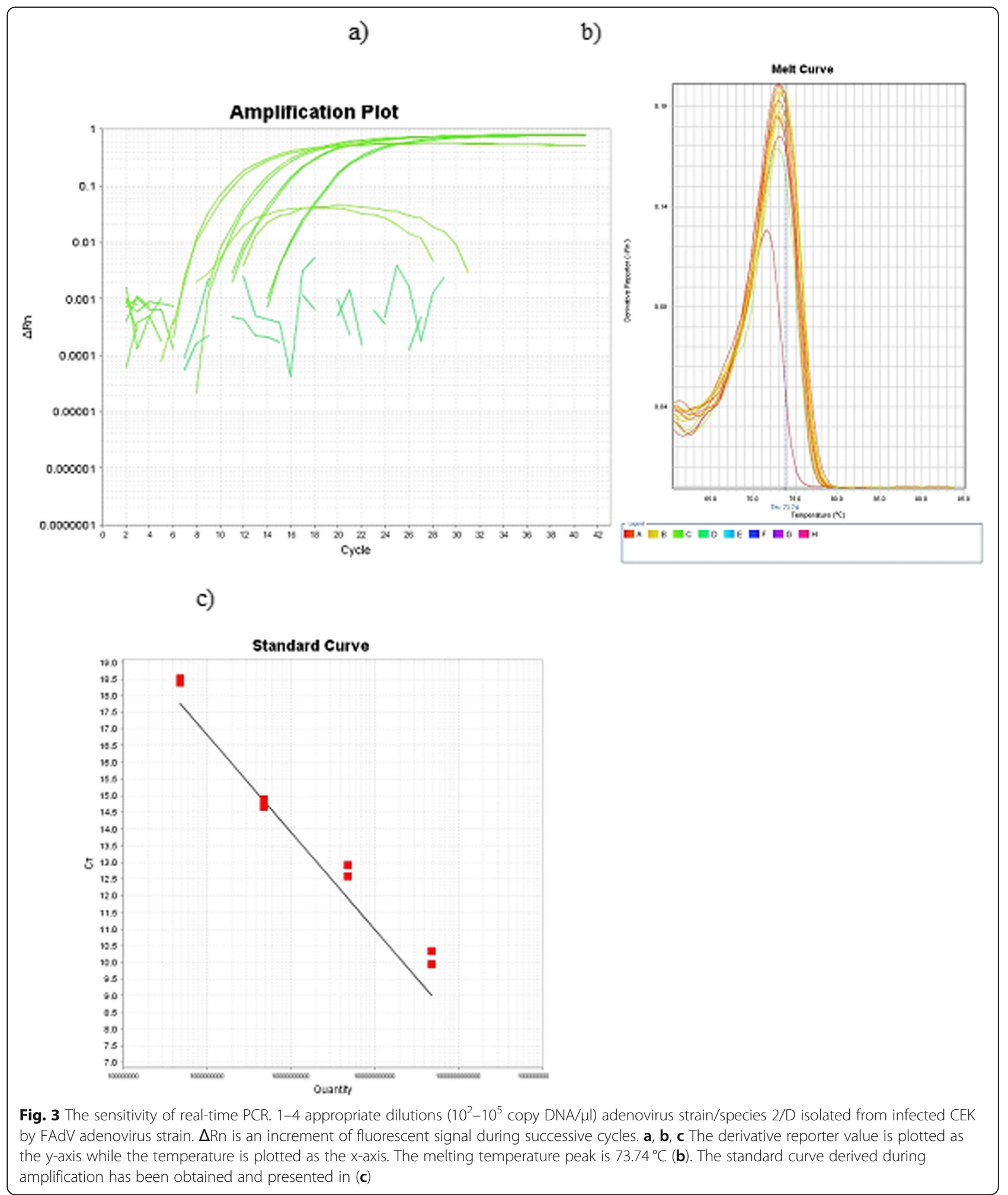

\section{Loop-mediated-isothermal-amplification and primer} selection

The nucleotide sequences of three pairs of primers used for the amplification of the FAdV hexon gene were previously designed, and all of the parameters were optimised by Niczyporuk [21]. LAMP was conducted as follows: final volume of $25 \mu \mathrm{l}$ of mastermix containing $1 \mathrm{x}$ buffer Pol $(50 \mathrm{mM}$ Tris- $\mathrm{HCl}, \mathrm{pH} 9.0,50 \mathrm{mM} \mathrm{NaCl}, 5$ 
a

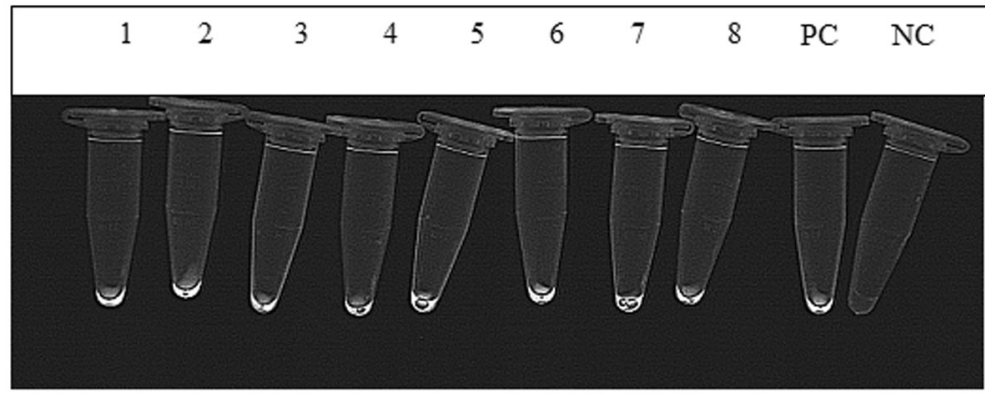

$\mathrm{b}$

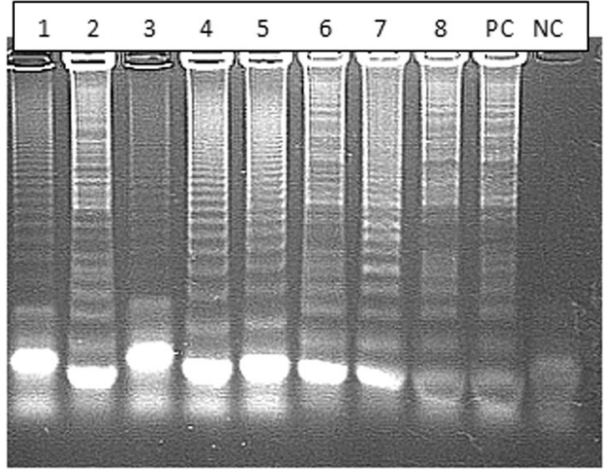

Fig. 4 a, $\mathbf{b}$ The results of the visual LAMP detection method of FAdV DNA under UV light. The upper part shows a Observation of fluorescence of positive samples under UV light illumination. Descriptions: NC negative control - DNA template extracted from non infected CEKs, 1-8) appropriate adenovirus field strains detected in wild birds samples, 9) PC - positive control - DNA of FAdV-2/D strain of adenovirus product corresponding to - UV fluorescence. The lower part shows $\mathbf{b}$ gel electrophoresis of LAMP products with the presence of ladder-like bands.

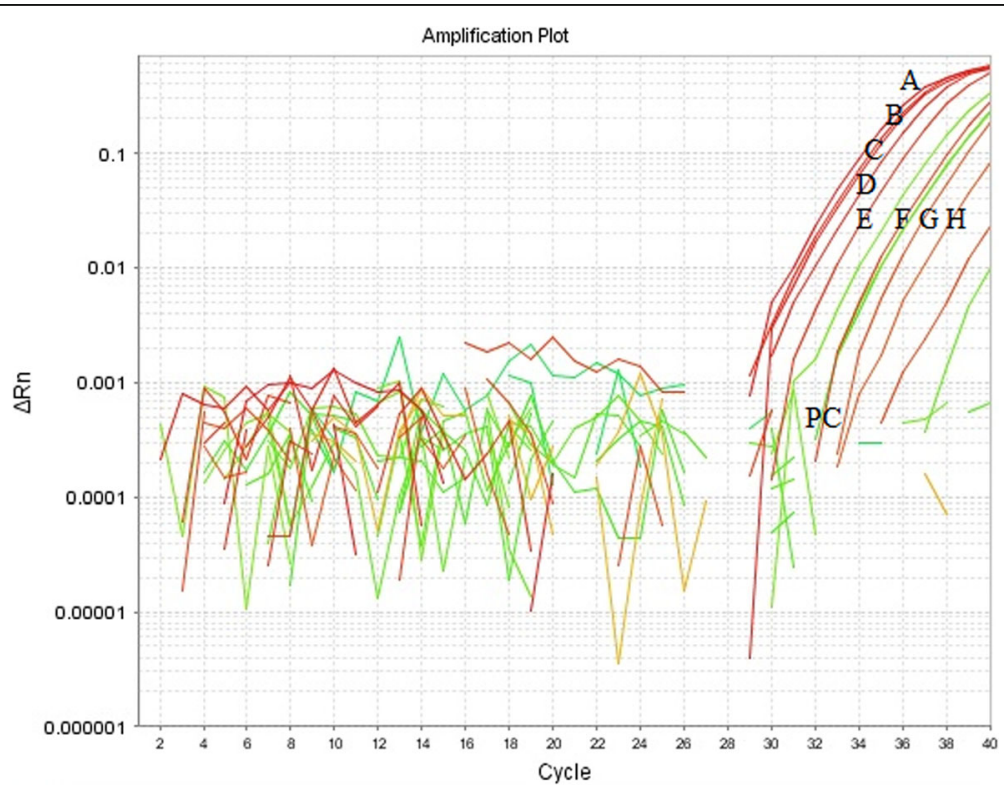

Fig. 5 Results obtained by real-time PCR. Amplification plot of real-time PCR for the detection of adenovirus strains. $\Delta R n$ is an increment of the fluorescence signal during successive cycles specific for the positive control and samples 1-8, as described: NC-DNA extracted from non-infected SPF CEKs, PC - positive control, DNA extracted from positive control 2/D and 1-8 positive samples 


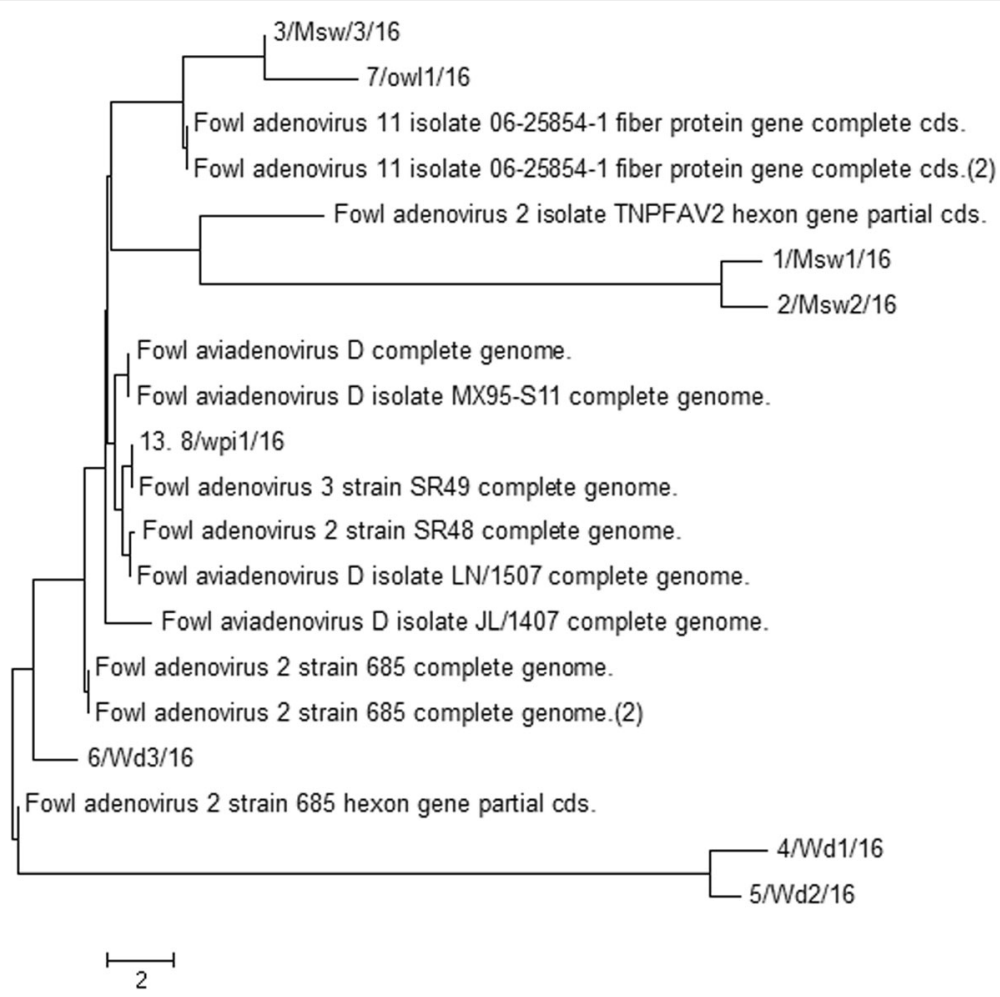

Fig. 6 The phylogenetic tree was based on a region of $830 \mathrm{bp}$ of the Loop L1 region of the hexon gene nucleotide sequence and was constructed using the maximum-likelihood method. The sequence of reference of adenovirus strains FAdV-2/3/11/D were used. Bootstrap percentages based on 1000 replicates are shown at the tree nodes. Evolutionary analysis was conducted using the MEGA7 software

$\mathrm{mM} \mathrm{MgCl}_{2}$ ) (EurX), 1.6 M betaine (Sigma-Aldrich), 1.5 mM - dNTPs (EurX), 50 pM of FIP JSN and BIP JSN internal primers, $10 \mathrm{pM}$ of F3 JSN and B3 JSN external primers, FIP $(\mathrm{F} 1 \mathrm{c}+\mathrm{F} 2) \mathrm{JSN}$ and BIP $(\mathrm{B} 1 \mathrm{c}+\mathrm{B} 2)$ JSN loop primers, $8 \mathrm{U}$ of polymerase Bst DNA (EurX), $2 \mu \mathrm{l}$ DNA of $30 \mathrm{ng}$, and deionised water.

\section{LAMP specificity and sensitivity}

The specificity, concerning the FAdV, CAV, HEV, and DAdV-1 viruses, and the sensitivity of the reference strains FAdV-2/D, 3/D and 11/D was published by Niczyporuk [21]. The electrophoresis of the amplicons was carried out in $2 \%$ agarose gel with $1 \mu \mathrm{g} / \mathrm{ml}$ of ethidium bromide, and was performed in a tris borate EDTA buffer, pH 8.2, with the use of Mini Sub-Cell (Biorad, USA) with $150 \mathrm{~V}$ and $80 \mathrm{~mA}$ for $50 \mathrm{~min}$. The size of the amplification products were compared with a DNA Mass Ruler 1031 bp (Fermentas). The results were visualised and documented using transilluminator UV (Geno Smart VWR Germany).

\section{Real-time PCR confirmation}

The sequences of nucleotide primers specific to the FAdV strains were designed based on the sequence of the Loop L1 HVR1-4 region of the hexon gene of reference strains FAdV-2/D KT862805 (ANJ02325), FAdV-3/
D KT862807 (ANJ02399) and FAdV-11/D KC750784 (AGK29904) amplifying the $93 \mathrm{bp}$ product, and were as follows: FAdV-JSN-F (sense primer): 5'AATGTCACNACCGARAAGGC3' and FAdV-JSN-R (antisense primer) 5'CBGCBTRCATGTACTGGTA3' and JSN-FAdV probe 5'AATCCCTACTCGAACACCCC3' simultaneously for $2 / 3 / 11 / D$. Primers were designed in the Primer 3 programme according to the GeneBank database and synthesised in the commercial company Genomed in Warsaw. Cycle threshold $(\mathrm{Ct})$ values from 23.07 to 24.51, indicating that there was no interference among the primers in the real-time PCR. Primers, were confirmed and used to evaluate the specificity and coverage. The real-time PCR have been performed by using Applied Biosystems 7500 Real-time PCR, and were used in a final volume of $25 \mu \mathrm{l}$. The mixture contained: $12.5 \mu \mathrm{l}$ of PCR Master Mix, $1.0 \mu \mathrm{l}$ of each primer FAdV-JSN-F and FAdV-JSN-R, $1.0 \mu \mathrm{l}$ of probe, $2.0 \mu \mathrm{l}$ of DNA, and $6.0 \mu \mathrm{l}$ of deionised water. Nucleotides, Taq DNA Polymerase and buffer were included in the one-step RT- PCR kit (Qiagen). The designed protocol took $138 \mathrm{~min}$. to obtain the results. The reaction conditions were as follows: $95^{\circ} \mathrm{C} / 15 \mathrm{~min}$ (initial denaturation), $94{ }^{\circ} \mathrm{C} / 30 \mathrm{~s}$ (primer annealing), then 41 cycles of $55^{\circ} \mathrm{C} / 45 \mathrm{~s}$ (exact denaturation), $72{ }^{\circ} \mathrm{C} / 1 \mathrm{~min}$ (signal acquisition). All reactions were carried out in duplicate with adequate melting 
curve analysis. As a positive control, total DNA extracted from the reference FAdV-2/D FAdV-3/D, and FAdV-11/D strains were used. As a negative control DNA obtained from non-infected CEK cells were used.

\section{Plasmid standards}

pHexon plasmid was constructed by cloning a $93 \mathrm{bp}$ fragment of the pHexon gene 2/D in pGEM-T Easy Vector (Promega, US) and Blue/White X-Gal/IPTG selection. The pHexon was then amplified in E.coli DH5 $\alpha$ (Invitrogen, US) in a liquid LB medium with the addition of $100 \mu \mathrm{g} / \mathrm{ml}$ of ampicillin at $37^{\circ} \mathrm{C}$ in a Max 4000Q apparatus (Barnstead/Lab-line). The extraction of plasmid DNA was isolated from $10 \mathrm{ml}$ of liquid of an 18 h culture of E.coli DH5 $\alpha$ cells using a Plasmid Maxi Kit (Qiagen, Germany).

\section{Quantification of FAdV}

The quantity of the exact copy number of the hexon gene in the examined samples was calculated in Applied Biosystems software (Version 2.0.1). The quantification of the viral copy number was calculated according to a procedure previously described by Gunes et al. [19] and Steer et al. [20]. On the basis of serial tenfold dilutions of the pHexon, which produced from $10^{2}$ to $10^{5} \mathrm{DNA}$ copies/ $1 \mu \mathrm{l}, 4$ point standard curves were prepared and used for the Hexon gene copy number calculation. The fluorescence curve indicated the amplification of specific fragments for the examined gene.

\section{Real-time PCR specificity and sensitivity}

Whole cell DNA from CAV, HEV and DAdV-1 were used to determine the method specificity. Standard curves for plasmid detection showed a dynamic range and high correlation coefficient $R^{2}>0.99$. Analysis with tenfold dilutions of whole cell DNA from the reference FAdV-2/D, 3/D and 11/D strains, which corresponds to DNA concentrations of between $10^{2}$ and $10^{5}$ DNA copies $/ 1 \mu \mathrm{l}$ were prepared. Taking $\mathrm{Ct}=35$ as the cut off value, the detection limit was 8 copies of virus genome (DNA) per reaction for 2/D, 3/D and 11/D respectively.

\section{Real-time PCR product analysis}

The crossing point of the fluorescence curve and the threshold line were calculated automatically by the thermocycler software with a proportional baseline adjustment setting. The fluorescence level was measured after the end of each annealing step. The quantification data were determined through a comparison of the $\mathrm{Ct}$ values of the samples with the $\mathrm{Ct}$ of standards prepared with 10-fold dilutions of plasmid DNA. In order to detect the limit of the assay, a series of 10 -fold dilutions from $10^{2}$ to $10^{5}$ of DNA were tested.

\section{Sequencing}

The assembly obtained to prove positivity for FAdV nucleotide sequence alignments were sequenced using a GS FLX/Titanium sequencer (Roche, Switzerland) by GENOMED (Poland). Phylogenetic analyses were performed by comparing the obtained nucleotide sequences of field adenovirus strains with the sequences of adenovirus strains obtained from the GenBank (NCBI) database. A phylogenetic tree was generated by the Neighbor-Joining method with the use of the p-distance method (on 1000 bootstrapped data sets). Molecular analysis was performed using MEGA7, Geneious7, and BLAST computer software. On the basis of this analysis, the similarity between the examined adenovirus strains were determined [34-36].

\section{Authors' contributions}

JSN, designed research; ISN, HC, WK, NSF and KP performed research; ISN wrote the first draft of the manuscript; JSN, WK, HC, NSF, and KP contributed to modify the manuscript. All authors read and approved the final manuscript.

\section{Funding}

No funding was received.

\section{Availability of data and materials}

The datasets supporting the conclusions of this article are included within the article.

\section{Ethics approval and consent to participate}

All the samples was collected under the permission in accordance with the local license.

This study did not include live animals in our experiments.

Consent for publication

No applicable.

\section{Competing interests}

The authors declare that they have no competing interests.

Received: 12 April 2019 Accepted: 31 January 2020

Published online: 14 February 2020

\section{References}

1. Benko M, Harrach B. Molecular evolution of adenoviruses. Curr Top Microbiol Immunol. 2003;272:3-35.

2. Harrach B, Kaján GL. Family adenoviridae. In: A.M.Q, King MJ, Adams EB, Carstens, Lefkowitz EJ, editors. Virus taxonomy: ninth report of the international committee on taxonomy of viruses. 9th ed. New York: Elsevier Academic Press; 2012. p. 125-41.

3. Notomi T, Okayama H, Masubuchi H, Yonekawa T, Watanabe K, Amino N, Hase T. Loop-mediated isothermal amplification of DNA. Nucleic Acids Res. 2000;28:e63

4. McConnell BA, Fitzgerald AS. Group I - adenovirus infections. Disease of Poultry. In: Saif YM, editor. Blackwell Publishing Professional. Ames: lowa State Press; 2008. p. 252-66.

5. Hess M. Detection and differentiation of avian adenoviruses: a review. Avian Pathol. 2000;29:195-206.

6. McFerran JB, Connor TJ, McCracken RM. Isolation of adenoviruses and reoviruses from avian species other than domestic fowl. Avian Dis. 1976;20: 519-24.

7. Shubhagata D, Fearnside K, Sarker S, Forwood JK, Raidal SR. A novel pathogenic aviadenovirus from red-bellied parrots (Poicephalus rufiventris) unveils deep recombination events among avian host lineages. Virology. 2017:502:188-97.

8. Kumar R, Kumar V, Asthana M, Shukla SK, Chandra R. Isolation and identification of a fowl adenovirus from wild black kites (Milvus migrans). J Wildl Dis. 2010;46:272-6. 
9. Forbes NA, Simpson GN, Higgins RJ, Gough RE. Adenovirus infection in Mauritius kestrels (falco punctatus). J Avian Med Surg. 1997;11:31-3.

10. Oaks $\sqcup$, Schrenzel $M$, Rideout $B$, Sandfort $C$. Isolation and epidemiology of falcon adenovirus. J Clin Microbiol. 2005;43:3414-20.

11. Schrenzel M, Oaks JL, Rotstein D, Maalouf G, Snook E, Sandfort C, Rideout B. Characterization of a new species of adenovirus in falcons. J Clin Microbiol. 2005;43:3402-13.

12. Frolich $\mathrm{KC}$, et al. Antibodies to adenoviruses in free living common buzzards from Germany. J Wildl Dis. 2005;38:633-6.

13. Reece RL, Pass DA. Inclusion body hepatitis in a tawny frogmouth (Podargus strigoides: Caprimulgiformes). Aust Vet J. 1985;62:426.

14. Bryant WM, Montali RJ. An outbreak of a fatal inclusion body hepatitis in zoo psittacines. In: Proceedings international conference on avian medicine, vol. 1; 1987. p. 473.

15. Lüschow C, Prusas M, Lierz H, Gerlach H, Hafez M. Adenovirus of psittacine birds: investigations on isolation and development of a real-time polymerase chain reaction for specific detection. Avian Pathol. 2007;36:487-94.

16. Vereecken $M$, de Herdt $P$, Ducatelle R. Adenovirus infections in pigeons: a review. Avian Pathol. 1998;27:333-8.

17. Schachner A, Matos M, Grafl B, Hess M. Fowl adenovirus-induced diseases and strategies for their control - a review on the current global situation. Avian Pathol. 2018;47:111-26.

18. Grgić H, Philippe C, Ojkić D, Nagy E. Study of vertical transmission of fowl adenoviruses. Can J Vet Res. 2006;70:230-3.

19. Gunes A, Marek A, Grafl B, Berger E, Hess M. Real -time PCR assay for universal detection and quantification of all five species of fowl adenoviruses (AFdV-A to FAdV-E). J Virol Methods. 2012;183:147-53.

20. Steer PA, Kirkpatrick NC, O'Rourke D, Noormohammadi AH. Classification of fowl adenovirus serotypes by use of high-resolution melting-curve analysis of the hexon gene region. J Clin Microbiol. 2009;47:311-21.

21. Niczyporuk JS. Molecular characteristic on occurrence of fowl adenovirus field strains and effect of efficiency on prophylactic vaccinations against Marek's disease. Pulawy: Doctoral dissertation, National Veterinary Research Institute; 2014.

22. Mockett AP, Cook JKA. The use of an enzyme-linked Immunosorbent assay to detect lgG antibodies to serotype-specific and group-specific antigens of fowl adenovirus serotypes 2, 3 and 4. J Virol Methods. 1983;7:327-35.

23. Niczyporuk JS, Samorek-Salamonowicz E, Czekaj H. Incidence and detection of aviadenoviruses of serotypes 1 and 5 in poultry by PCR and duplex PCR. J Vet Sci. 2010:54:451-5.

24. Romanowa N, Corredor JC, Nagy E. Detection and quantification of fowl adenovirus genome by a real-time PCR assay. J Virol Methods. 2009:159:58-63.

25. Singh A, Oberoi MS, Grewal GS, Hafez HM, Hess M. The use of PCR combined with restriction enzyme analysis to characterize fowl adenovirus field isolates from northern India. Vet Res Commun. 2002;26:577-85.

26. Taketoshi W, Ryoko Y, Tetsuhiko K. Rapid and sensitive diagnosis of adenoviral keratoconjunctivitis by loop-mediated isothermal amplification (LAMP) method. Curr Eye Res. 2004;6:445-50.

27. Niczyporuk JS. Adenoviruses and Their Diversity in Poultry. In: Application of Genetics and Genomics in Poultry Science, License CC BY 3.0; 2018. https:// doi.org/10.5772/intechopen.77131.

28. Gerlach H. Viruses. In: Ritchie BW, Harrison GJ, Harrison LR, editors. Avian medicine: principles and application. Florida: Wingers Publishing Lake Worth; 1994. p. 862-948.

29. Schelling SH, Garlick DS, Alroy AND. Adenoviral hepatitis in a merlin (Falcocolurnberlus). Vet Pathol. 1989;26:529-53.

30. Xie Z, Tang Y, Fan Q, Liu J, Pang Y, Deng X, Xie Z, Peng Y, Xie L, Khan MI. Rapid detection of group I avian adenoviruses by a loop-mediated isothermal amplification. Avian Dis. 2011;55:575-9.

31. Heim A, Ebnet C, Harste G, Pring-Akerblom PJ. Rapid and quantitative detection of human adenovirus DNA by real-time PCR. Med Virol. 2003; 70(2):228-39.

32. Gwangpyo KG, Jothikumar N, Hill VR, Sobsey MD. Rapid detection of infectious adenoviruses by mRNA real-time Rt-PCR. J Virol Methods. 2005; 127:148-53.

33. Reed $L$, Muench $J H$. A simple method of estimating fifty percent endpoints. Am J Epidemiol. 1938;27:493-7.

34. Katoh K, Standley DM. MAFFT multiple sequence alignment software version 7: improvements in performance and usability. Mol Biol Evol. 2013; $30: 772-80$.
35. Kearse M, Moir R, Wilson A, Stones-Havas S, Cheung M, Sturrock S, Buxton S, et al. Geneious basic: an integrated and extendable desktop software platform for the organization and analysis of sequence data. Bioinformatics. 2012;28:1647-9.

36. Larkin MA, Blackshields G, Brown NP, Chenna R, McGettingan PA, McWilliam $H$, et al. Clustal W and Clustal X version 2.0. Bioinformatics. 2007;23:2947-8.

\section{Publisher's Note}

Springer Nature remains neutral with regard to jurisdictional claims in published maps and institutional affiliations.
Ready to submit your research? Choose BMC and benefit from:

- fast, convenient online submission

- thorough peer review by experienced researchers in your field

- rapid publication on acceptance

- support for research data, including large and complex data types

- gold Open Access which fosters wider collaboration and increased citations

- maximum visibility for your research: over $100 \mathrm{M}$ website views per year

At BMC, research is always in progress.

Learn more biomedcentral.com/submissions 